\title{
Penyimpangan-Penyimpangan dalam Penafsiran Al-Quran dan Efek Negatifnya Pada Aqidah Umat
}

\author{
Lufaefi \\ Mahasiswa Jurusan Ilmu Al-Quran dan Tafsir PTIQ Jakarta \\ eepivanosky@gmail.com
}

Diterima 15 Juli 2018 | Direview 27 September 2018|Diterbitkan 01 Desember 2018

\begin{abstract}
:
Al-Quran is a text that is free to be interpreted by anyone from its readers. As a dead text (unable to speak alone) allows itself to be interpreted according to the will of the interpreter. It is this background that gives rise to a variety of Koranic interpretations. However, it then also gives rise to forms of interpretation that come out of the ruling interpretation of the Koran, which later became known as deviant interpretations. Through research studies of Library, this paper will reveal forms of misinterpretation and negative effects for Muslims. This deviation of interpretation has extended to various modes of interpretation itself, such as being included in bistorical interpretations, theological opinions, Sufi interpretations, linguistic interpretations, scientific interpretations, even modern interpretations. These deviations have a devastating negative effect, such as assuming Islamic teachings are not authentic, mixing Islam with non-Muslims, misunderstanding the content of the Koran, and degrading salaf scholars.
\end{abstract}

Keywords: Interpretation Deviation, Aqidah Damage, Deviation Factor, Israiliyyat.

\begin{abstract}
Abstrak:
Al-Quran merupakan teks yang bebas ditafsiri oleh siapa saja dari pembacanya. Sebagai teks yang mati (tidak dapat berbicara sendiri) memungkinkan dirinya diinterpretasikan sesuai kemauan penafsirnya. Latar belakang inilah yang memunculkan beragam corak tafsir alQuran. Akan tetapi hal itu kemudian juga menimbulkan bentuk-bentuk penafsiran yang keluar dari rel tafsir al-Quran, yang kemudian dikenal sebagai tafsir-tafsir yang menyimpang. Melalui telaah research kepustakaan, tulisan ini akan mengungkap bentuk-bentuk penyimpangan tafsir dan efek negatifnya bagi akidah umat Islam. Penyimpangan tafsir ini sudah meluas ke berbagai corak tafsir itu sendiri, seperti masuk dalam tafsir historis, tefsir teologis, tafsir sufi, tafsir linguistik, tafsir ilmi, bahkan tafsir modern. Penyimpanganpenyimpangan ini memberi efek negatif yang dahsyat, seperti menganggap ajaran Islam tidak otentik, mencampuradukan agama Islam dengan non-Islam, sesat memahami kandungan alQuran, dan merendahkan ulama salaf
\end{abstract}

Kata Kunci: Penyimpangan Tafsir, Kerusakan Aqidah, Faktor Penyimpangan, Israiliyyat.

\section{Pendahuluan}

Al-Quran adalah kitab suci bagi umat Islam di seluruh dunia. Kedudukannya memiliki posisi yang sangat sakral bagi mereka. Di dalamnya terkandung aspek-aspek yang universal, sehingga tidak semua ayatnya mudah dipahami oleh umat Islam. Hal ini yang kemudian menurut Quraish Shihab, terdapat ayat-ayat yang sulit untuk dimengerti dan diperlukanlah sebuah tafsiran, bahkan diharuskan untuk menelitinya. ${ }^{1}$ Dari situlah kemudian muncul ilmu tafsir, yaitu ilmu yang digunakan untuk memahami maksud Allah Swt di dalam al-Quran melalui petunjuk-petunjuknya sesuai kemampuan manusia. ${ }^{2}$ Dalam tafsir sendiri secara garis besar telah muncul metode tafsir bil ma'tsur, bi al-ra'yi dan isyari. ${ }^{3}$ Meskipun demikian, bukan

\footnotetext{
${ }^{1}$ M. Quraish Shihab, Kaidah Tafsir: Syarat, Ketentuan dan Aturan yang Patut Anda Ketahui dalam Memahami Al-Quran, (Tangerang: Lentera Hati, 2013), h. 5.

${ }^{2}$ Muhammad Husain Ad-Dzahabi, Ilmu Tafsir, (Kairo: Dar al-Ma'arif, t.th), h. 6.

${ }^{3}$ Manna al-Qatthan, Mababits Fi Ulum al-Quran, (Kairo: Maktabah Wahbiyyah, 195), h. 325.
} 
berarti dengan metode-metode tersebut membebaskan suatu penafsiran lepas dari penyimpangan dan kesalahan dalam menafsirkan ayat-ayat al-Quran.

Ozi Setiady dalam penelitiannya, menyebutkan bahwa penyimpangan-penyimpangan dalam penafsiran al-Quran disebabkan oleh faktor yang berasal dari intern pribadi Mufasirnya. Selain itu, faktor eksternal juga mewarnai tafsir-tafsir al-Quran yang dianggap menyimpang, seperti faktor politik, kisah-kisah orang Yahudi-Nasrani, dan perbedaan mazhab teologi. ${ }^{4}$

Tentu saja, melihat kedudukan al-Quran sebagai petunjuk bagi manusia (budan linnas), melakukan penyimpangan dalam penafsiran al-Quran secara otomatis akan menyimpangkan umat manusia dari petunjuk yang sebenarnya. Bahkan bisa jadi, dapat menyesatkan pemahaman mereka terhadap ayat-ayat suci al-Quran.

Adanya faktor-faktor yang menyebabkan terjadinya penyimpangan dalam tafsir alQuran, membuat penulis tergerak untuk melakukan kajian secara khusus terkait hal di atas. Dalam makalah ini akan dikaji apa makna penyimpangan dalam tafsir; faktor-faktor apa saja yang menyebabkan terjadinya penyimpangan; dan macam-macam bentuk penyimpangan dalam penafsiran al-Quran.

\section{Memahami Definisi Tafsir}

Kata Tafsir bersal dari kata fassara yang berarti menjelaskan, membuka serta menjelaskan yang ma'qul. Pengertian tafsir mempunyai kelaziman tersendiri dalam bahasa Arab, dimana bentuk masdar sering diberi bentuk isim maf'ul dengan arti yang dihasilkan. Oleh karena itu pengertian tafsir dibedakan atas dua macam:

1. Tafsir sebagai masdar berarti menguraikan dan menjelaskan apa-apa yang terkandung dalam Al-Quran berupa makna-makna, rahasia-rahasia dan hukumhukum.

2. Tafsir sebagai maf'ul berarti ilmu yang membahas koleksi sistematis dari natijah penelitian terhadap Al-Quran dari segi dilalah-nya yang dikehendaki Allah sesuai dengan kadar kemampuan manusia. ${ }^{5}$

Tafsir dapat dirumuskan melalui pendapat para cendekiawan yang di dalam penjelasannya terdapat kesepahaman dalam mendefinisikan tafsir, seperti Jalaluddin AsSuyuthi, Imam Abu Hayyan, Hasbie Ash-Shiddiqie, dan Az-Zarkasyi. Mereka menjelaskan bahwa tafsir adalah ilmu tentang Al-Quran yang di dalamnya terdapat sebab turun Al-Quran, letak turunnya ayat Al-Quran (makkiyah dan madaniyyah), lafadz, hukum, redaksional, makna dan segala hal yang terkait dengan Al-Quran. ${ }^{6}$

\section{Syarat-Syarat Penafsir al-Quran (Mufassir)}

Secara sederhana, Mufasir adalah orang atau ulama yang melakukan aktivitas penafsiran al-Quran. Terkait dengan pengertian ini, Husain ibn Ali Ibn Husain al-Harby menyatakan bahwa Mufasir adalah orang yang memiliki kapabilitas yang sempurna yang dengannya ia dapat memahami maksud Allah Swt di dalam al-Quran; ia juga mampu memahami manhaj-manhaj Mufasir sebelumnya, sehingga ia mengetahui akan keberagaman tafsir itu sendiri; dan ia mengajarkannya pada yang lain serta mengamalkannya. ${ }^{7}$

${ }^{4}$ Ozi Setiady, Faktor-Faktor Penyebab Penyimpangan dalam Tafsir, dalam penelitian pribadinya, h. 3 .

5Komarudin Hidayat, Memahami Bahasa Agama (Jakarta: PT Temprint, 1996), h. 175.

${ }^{6}$ Hasby Ashiddiqy, Sejarah dan Pengantar Ilmu Hadits, (Semarang: Pustaka Rizki Putra, 1999), h. 122.

${ }^{7}$ Husain ibn Ali Ibn Husain al-Harby, Qawa'id at-Tariih 'Inda al-Mufassir: Dirasab Nazhariyyah Tabtbiqiyyah, (Riyadh: Dar al-Qashim, 1996), juz 1, h. 29. 
Quraish Shihab mengkategorikan syarat-syarat seseorang dikatakan sebagai Mufassir ${ }^{8}$, yaitu: mengetahui bahasa Arab dan segala bidangnya; mengetahui ilmuilmu al-Quran, asbab an-nuzul, hadis-hadis dan juga ushul al-figh; mengetahui tentang ilmu keagamaan; mengetahui ilmu-ilmu yang akan menjadi pembahasan dalam tafsir. Sedangkan Manna Khalil Qhathtan menjelaskan syarat-syarat bagi seseorang yang hendak menjadi Mufassir ${ }^{9}$, yaitu sebagai berikut:

1. Aqidah yang benar, aqidah akan memberi efek bagi seseorang yang membuat sebuah karya tafsir. Ketika aqidah seseorang tidak benar maka akan menyesatkan umat. Tafsir yang ia buat ditujukan hanya untuk kepentingan kelompoknya saja.

2. Membuang hawa nafsu, hawa nafsu juga menjadikan seseorang akan mementingkan mazhabnya sendiri. Sebagaimana tafsir-tafsir dari kalangan Syiah Rafidzah dan Mu'tazilah.

3. Mendahulukan tafsir al-Quran bi al-Quran, satu ayat dengan ayat lainnya saling berkaitan, oleh sebab itu menafsirkan al-Quran harus mengutamakan penafsiran dengan ayat al-Quran lainnya.

4. Menafsirkan dengan Sunnah Ketika di dalam al-Quran tidak ditemukan penafsiran bagi ayat lain, maka digunakanlah Sunnah Nabi Muhammad Saw. Hal itu sebab apa yang diucapkan Nabi ialah al-Quran itu sendiri (al-Qur'an nathiq). Sebagaimana Imam Syafi'I juga menyatakan bahwa apa-apa yang difaham dri Nabi adalah penafsiran al-Quran.

5. Menafsirkan dengan Qaul Sahabat, jika dalam al-Quran dan Sunnah tidak menemukan, maka selanjutnya menafsirkan dengan ungkapan para sahabat. Sebab mereka mengetahui kehidupan nabi dan juga memiliki ilmu yang tidak dapat diragukan.

6. Menafsirkan dengan Qaul tabi'n dan tabi'it tabi'in ketika tidak ditemukan isyarat dari qaul sahabat, maka langkah selanjutnya adalah menafsirkan dengan pernyataan-pernyataan dari tabi'it tabi'in, seperti Imam Mujahid Ibn Jubair, Sa’id Ibn Jubair dan Ikrimah yang merupakan budak Ibn Abbas.

7. Menafsirkan dengan perangkat kebahasaan karena al-Quran merupakan bahasa Arab, maka memahami bahasa Arab bagi seorang Mufasir adalah suatu keharusan. Imam Mujahid, menyatakan bahwa tidaklah diperbolehkan siapa saja yang beriman kepada Allah dan hari akhir, yaitu untu menafsirkan al-Quarn, sedang ia tidak menguasai bahasa Arab.

8. Memahami ilmu-ilmu yang berkaitan dengan al-Quran, ilmu-ilmu tersebut seperti ilmu-ilmu tafsir, ilmu tauhid dan ilmu-ilmu qira'at. Dengan begitu seorang Mufasir tida kana menyelewengkan wujud Allah dengan sifat-sifat yang melekat padanya. Ia pun dengan ilmu-ilmu tafsir akan melakukan proses penafsirannya sesuai dengan kaidah-kaidah tafsir yang benar.

9. Pemahaman yang kuat, melalui pemahaman agama yang kuat, khususnya terkait ilmu-ilmu agama, akan menjadikan seorang Mufassir mampu untu mmebandingkan dan menganalisa pendapat-pendapat lain dari dirinya.

Shabur Hasan Muhammad Abu Sulaiman, dalam kitabnya Maurid ad-Dham'an fi Ulum al-Quran, menyebutkan syarat-syarat seorang Mufassir sama dengan apa yang

${ }^{8}$ M. Quraih Shihab, Kaidah-Kaidab Tafsir, (Tangerang: Lentera, 2007), h. 79.

${ }^{9}$ Manna Khalil Qhaththan, Mababis Fi Ulum al-Quran, (Mesir: Maktabah Wahbiyyah, t.th), h. $321-323$. 
disebutkan oleh Manna Khalil Qhaththan. Akan tetapi ia merinci maksud dari pemahaman yang kuat ialah menguasai ilmu-ilmu sebagai berikut, yaitu ilmu bahasa, nahwu, sharf, isytiqaq, ma'ani, badi', bayan, ilmu qira'at, ushuluddin, ushul al-syari'ah, ushul al-fiqh, asbab an-nuzul, nasikh mansukh, fiqh, ilmu hadis dan ilmu wahbiyyah (pemberian langsung dari Allah atau Rasul-Nya). ${ }^{10}$

Dari penjelasan di atas, dua kategorisasi yang dibuat oleh Quraish Shihab dan Manna Khalil Qhaththan pada dasarnya adalah sama, sehingga, hemat penulis, pendapat keduanya secara bersamaan menjadi ketentuan umum bagi seorang yang hendak menafsirkan al-Quran.

\section{Memahami Penyimpangan Tafsir}

Dalam Kamus Besar Bahasa Indonesia (KBBI) menyatakan, ada beberapa arti kata menyimpang antara lain adalah: 1). Membelok atau menempub jalan yang lain, 2). Membelok supaya jangan melanggar atau terlanggar, 3). Tidak menurut apa yang sudah ditentukan, 4). Menyalabi kebiasaan, 5) Menyeleweng (dari bukum, kebenaran agama dll). ${ }^{11}$ Adapun yang sesuai dengan masalah ini adalah mengambil makna yang ketiga atau kelima yakni tidak menurut aturan-aturan yang ada sehingga melanggar hukum agama.

Adapun para ulama mengatakan bahwa penyimpangan dalam bahasa Arab adalah Syadz. Sedangkan ahli bahasa sepakat bahwa lafadz Syudzudz secara bahas berarti menyendiri dan berpisah. ${ }^{12}$ Jika kita mengatakan Syadzdza Arrajulu artinya adalah seseorang menyendiri dari teman-temannya.

Sedangkan secara istilah ulama berbeda pendapat, di antaranya sebagai berikut:

1. Menurut ahli qira'at, Syadz adalah qiroat yang tidak memenuhi satu syarat dari syarat qiroat shahih.

2. Menurut ulama ahli hadits, Syadzialah:

$$
\text { ما رؤاه الثقة خالفا لغيره }
$$

Artinya : Periwayatan orang tsiqoh yang menyalabi periwayatan orang lain.

3. Menurut Mufassir, Syadz adalah Penafsiran yang menyimpang dari metode yang diakui atau mengikuti sekte akidah yang batil atau menyalahi ijma' yang ditetapkan. ${ }^{13}$

Adapun yang dimaksud dengan penyimpangan tafsir Al-Quran adalah aturanaturan yang salah serta menyimpang yang tidak sesuai dengan kaidah tafsir dalam usaha memahami atau mempelajari ilmu-ilmu yang terkandung dalam Al-Quran yang didasarkan pada nafsu bukan karena ilmu.

\footnotetext{
${ }^{10}$ Shabur Hasan Muhammad Abu Sulaiman, Maurid ad-Dham'an Fi 'Ulum al-Quran, (India: Dar as-Salafiyyah, 1982), cet I, , h. 192-194.

${ }^{11}$ Nurdyanto, dkk, Kamus Besar Bahasa Indonesia, Jakarta: Badan Pengembangan dan Pembinaan Bahasa, 2016), edisi V, h. 155.

${ }^{12} \mathrm{Abu}$ al-Hasan Ali Ibn Hasan al-Wahidi, Al-Wasith FI Tafsir al-Quran wal Majid, (Kairo: Dar al-Kutub al-Ilmiyyah, t.th), jilid II, h. 313.

${ }^{13}$ Abdurrahman Ibn Salih Ibn Sulaiman, al-Ahwal al-Syaddab fi-Tafsir, (Saudi: Silsilah Ishdariyyat, t.th), h. 21-26.
} 
Penyimpangan dalam penafsiran lahir dari adanya hawa nafsu sang penafsir untuk mengalihkan makna satu ayat ke makna yang sesuai dengan keinginan hawa nafsunya. Dengan kata lain, adanya prakonsepsi yang dibenarkan melalui penafsiran. Mengabaikan ketentuan-ketentuan yang disepakati oleh yang memiliki otoritas dalam satu disiplin ilmu juga dapat dinilai sebagai penyimpangan walaupun hasilnya benar. Ini serupa dengan sikap guru mata pelajaran Matematika yang mempersalahkan siswa yang mengambil teori yang beda yang belum diajarkan oleh sang guru kendati angka yang dihasilkan adalah benar.

Dalam konteks ini harus dipahami sebuah riwayat yang dinisbatkan kepada Rasulullah Saw:

$$
\text { من قال في القران برايه فاصاب فقذ اخظا }
$$

"Barang siapa yang berbicara tentang Al-Quran dengan pendapatnya sendiri kemudian ternyata benar dalam penafsirannya, maka sesunggubnya dia telah bersalab". ${ }^{14}$

Maksudnya siapa yang menafsirkan Al-Quran pada pendapatnya sendiri yang tidak didasarkan pada ketentuan keilmuan dalam penafsiran dan tidak berlandaskan dalil yang sudah ditetapkan, dan sekalipun hasilnya benar, maka dia bersalah. Sebaliknya, orang yang menyimpulkan maknanya berlandaskan ilmu dan dasar-dasar yang kuat maka orang tersebut mendapatkan pujian dan pahala dari Allah Swt.

\section{Faktor-Faktor Pendorong Penyimpangan}

Sebagai wahyu yang mati (tidak mampu berbicara sendiri), al-Quran memiliki kemungkinan besar ditafsirkan dengan sesuai kemauan penafsirnya. Kedudukannya sebagai petunjuk bagi manusia (budan li an-nas) juga menjadikannya didekati oleh siapapun yang menghendaki interaksi dengannya. Sampai di sinilah penyimpanganpenyimpangan sebuah tafsir al-Quran tidak dapat dihindarkan.

Berikut ialah faktor-faktor yang menyebabkan munculnya penyimpanganpenyimpangan dalam penafsiran al-Quran:

1. Penghilangan Sanad-Sanad

Pada periode ketiga ${ }^{15}$, para ulama - khususnya dalam tafsir-tafsir bil ma'tsur - meriwayatkan tafsir melalui mufasir sebelumnya tanpa menyebutkan nama mufaisr yang disebutkan. Atau, penghilangan sanad-sanad hadis, dan hanya menyantumkan matan hadis. Sehingga dengan demikian, akurasi dan kebenaran sebuah tafsir sulit untuk diidentifikasi. Tahap inilah yang kemudian memunculkan israiliyyat dalam tafsir al-Quran. ${ }^{16}$

2. Munculnya Beragam Mazhab sekaligus Ambisi Pribadi dan Kelompoknya

Di dalam Islam, muncul berbagai mazhab Islam sejak terbunuhnya khalifah Ali Ibn Abi Thalib. Kran bermazhab itu pun semakin meluas pasca peristiwa tabkim (arbritase). Karena kemeluasannya tersebut muncul tafsir-tafsir al-Quran yang diklaim berasal dari Rasulullah Saw, yang padahal hanya dibuat-

${ }^{14}$ Abdurrahman Ibn Salih Ibn Sulaiman, al-Ahwal al-Syaddah fi-Tafsir, h. 26.

${ }^{15}$ Ad-Dzahabi, sebagaimana dikutip Said Agil Husain Munawwar, membagi perkembangan tafsir pada tiga periode, yaitu periode pertama; periode Nabi Muhammad Saw dan sahabatnya. Periode kedua; periode tabiin. dan periode ketiga adalah masa kodifikasi. Lihat: Said Agil Husain Munawwar, Ijaz al-Quran dan Metodoogi Tafsir, (Semarang: Dina Utama, 1994), h. 28.

${ }^{16}$ Muhammad Husain Ad-Dzahabi, Penyimpangan-Penyimpangan dalam Penulisan Al-Quran, (Jakarta: CV. Rajawali, 1986), h. 8. 
buat demi kepentingan semata, demi mendapatkan perhatian dari umat Islam. ${ }^{17}$ Saat itu setiap kelompok berusaha keras membuat pernyataan dengan mengutip al-Quran beserta penafsiran al-Qurannya, yang dinisbatkan pada Rasulullah, yang padahal tidak, bahkan sebaliknya. Akibatnya berbagai macam ilmu tercampuraduk. ${ }^{18}$

Keberlanjutan penyimpangan dalam menafsirkan al-Quran sampai pada Dinasti Abbasiyah. Demi mencari pengikut mazhab yang diyakini, penjualan ayat-ayat al-Quran pada saat itu sulit untuk dihindarkan. ${ }^{19}$

3. Mufasir Meyakini Kebenaran Suatu Makna, kemudian darinya itu dipergunakan untuk Merangkai berbagai Lafaz al-Quran. ${ }^{20}$

Al-Quran memiliki berbagai bentuk tafsiran dalam setiap ayat-ayatnya, bahkan hurufnya. Hal itu yang juga dijelaskan oleh al-Quran sendiri bhwa jika lautan menjadi tinta untuk menuliskan kandungan isi al-Quran, niscaya tidak akan pernah cukup, sebelum habisnya, meskipun Allah tambahkan air lautan tersebut. $^{21}$

Dari penjelasan makna di atas dipahami bahwa al-Quran memiliki kandungan makna yang begitu luas. Hanya meyakini sebuah tafsir dan digunakan untuk menjustifikasi tafsiran ayat-ayat al-Quran lainnya adalah sebuah penyimpangan yang nyata.

4. Mufaisrnya hanya berkutat pada bahasa Arab, tanpa mengetahui siapa yang berbicara, kepada siapa al-Quran itu diturunkan dan siapa yang dibicarakan dalam al-Quran. ${ }^{22}$

Tafsir demikian, lumrahnya hanya berkutat kepada teks saja, tanpa mempertimbangkan ruang dan waktu kapan tafsir al-Quran tersebut dimunculkan ${ }^{23}$ Di sisi lain, tafsir yang berkutat pada bahasa ini bertolak belakang dengan prinsip al-Quran yang sesuai dengan ruang dan waktu. ${ }^{24}$

5. Kisah-kisah Israiliyyat. ${ }^{25}$

Persesuaian antara al-Quran dan Taurat dan Injil menyisakan problem tersendiri dalam tafsir. Kedudukan Taurat dan Injil yang merincikan pembahasan dan penjelasan terkait beberapa hal yang ada dalam al-Quran yang hanya disebutkan secara global - menjadikan mufasir al-Quran menganggap ketidakapa-apaan untuk menjadikan penjelasan di dalam kitab suci Ahl al-Kitab tersebut sebagai penjelasan lebih rinci dari al-Quran. ${ }^{26}$

\footnotetext{
${ }^{17}$ Ahmad Musthofa Hadna, Problematika Menafsirkan al-Quran, (Semarang: Dina Utama, 193), h.
} 49.

${ }^{18}$ Muhammad Husain Ad-Dzahabi, Penyimpangan-Penyimpangan dalam Penulisan Al-Quran, h. 50.

${ }^{19}$ Khalid Abdurrahman al-'Akk, Ushul at-Tafsir wa Qawadi’ibi, (Irak: Dar al-Nukhais, t.th), h. 34.

${ }^{20}$ Ahmad Musthofa Hadna, Problematika Menafsirkan al-Quran, h. 50.

${ }^{21}$ Qs. Al-Kahfi Ayat 109.

${ }^{22}$ Ahmad Musthofa Hadna, Problematika Menafsirkan al-Quran, h. 50.

${ }^{23}$ Abdur Rachim; Tafsir Kontekstual, (majalah al-Jami’ah; IAIN Sunan Kalijaga, 1989), No. 39, h 41. Definisi tersebut didasarkan kepada makna "konteks" dalam kamus oxford, yaitu: susunan kata yang dipahami secara khusus, karena keterkaitan kata demi kata dalam susunan bahasa dan keterkaitannya pula dengan situasi dan kondisi yang melingkupinya. Lihat: The new oxford Illustrated Dictionary, (Oxford Univ. Press, USA, 1978), vol.1, h.359.

24 Ahmad Yusuf Sulaiman, Asbab al-Ikhtilaf fi Tafsir al-Quran, (Kairo: t.pn, 2011), h. 65.

${ }^{25}$ Ahmad Musthofa Hadna, Problematika Menafsirkan al-Quran, h. 144.

26 Usman, Imu Tafsir, (Yogyakarta: Teras, 2009), h. 37. 
Begitupun seterusnya, masa-masa tabi'in mulai banyak penyelundupkan israiliyat kepada tafsir al-Quran, karena dengan beberapa sebab, yaitu pertama, semakin banyaknya Ahlul Kitab yang masuk Islam. Kedua, adanya keinginan dari orang Islam untuk megetahui kisah-kisah yang lebih lengkap terkait kisahkisah Yahudi dan Nasrani . Masa-masa inilah yang kemudian mengisi kekosongan para mufasir untuk mengisi tafsir al-Quran dengan kisah-kisah yang menyimpang, takhayyul bahkan khurafat. Mereka beranggapan bahwa tidak perlu membuang kisah-kisah demikian, sekalipun tidak dibenarkan untuk dijadikan sebagai tafsir al-Quran. ${ }^{27}$

6. Kurangnya Pemahaman Mufasir terhadap Penguasaan bahasa Arab

Kegiatan-kegiatan penafsiran al-Quran yang dilakukan oleh orangorang yang tidak memiliki pengetahuan yang memadai tentang kaidah tafsir dan bahasa Arab, cenderung melakukan penyimpangan dalam menafsirkan alQuran dan memberi arti etimologi suatu lafal al-Quran yang tidak sesuai baik dalam hakikatnya atau kiasannya. ${ }^{28}$

Menguasai bahasa Arab dengan maksimal juga dijelaskan oleh Hadi Ma'rifah dalam at-Tafsir wal Mufassirun, yaitu sebagai salah satu syarat seseorang menafsirkan al-Quran. ${ }^{29}$ Keberadaaan al-Quran yang diturunkan dengan bahasa Arab, bagaimana mungkin untuk memahaminya tanpa penguasaan bahasa Arab?. ${ }^{30}$

7. Munculnya Para Penganut Tafsir 'Ilmi.

Para ulama zaman dahulu dan bahkan sekarang, meyakini bahwa selain ilmu agama, al-Quran juga mencakup ilmu-ilmu duniawi dengan segala macam coraknya. Mereka berusaha mencari istilah-istilah dalam al-Quran dan mengklaimnya sebagai bukti ilmu-ilmu kealaman. ${ }^{31}$ Para penganut tafsir ilmi mencoba mengaitkan apa-apa yang ada dalam al-Quran sebagai bukti realitas keberadaan alam. Mereka juga menjadikan al-Quran sebagai alat untuk memerhatikan gejala-gejala alam dan juga gejala pada dirinya. ${ }^{32}$ Kemunculan tafsir-tafsir ilmi yang berusaha mencari istilah-istilah dalam al-Quran guna melegalkan ilmu-ilmu kealaman ini yang biasa dikenal dengan tabmil al-Quran. ${ }^{33}$

8. Munculnya Pembaharu-Pembaharu Islam yang Sedikit Memiliki Pengetahuan Syari'ah

Mereka yang demikian berpendapat bahwa dengan membaharui penafsiran al-Quran, walaupun dianggap menyimpang dalam aturan penafsiran, tidaklah mengapa. Mereka berkeyakinan bahwa dengan melakukan penafsiran sesuai kemauan dan secara bebas, maka akan menyelamatkan al-Quran dari tuduhan sebagai teks yang parsial, atomistik dan tidak berkembang. Tafsir al-

\footnotetext{
${ }^{27}$ Muhammad Husain Ad-Dzahabi, Penyimpangan-Penyimpangan dalam Penulisan Al-Quran, h. 10.

${ }_{28}$ Muhammad Husain Ad-Dzahabi, Penyimpangan-Penyimpangan dalam Penulisan Al-Quran, h. 10.

${ }^{29}$ Muhammad Hadi Ma'rifah, At-Tafsir wal Mufassirun, (Iran: Muassisah Li At’Tab' wa al-Nashr,

${ }_{30}$ Muhammad Ibn Abdilah al-Hudhari, Tafsir at-Tabiin, (Saudi: Dar al-Wathani, t.th), jilid II, h.

${ }^{31}$ Muhammad Husain Ad-Dzahabi, Penyimpangan-Penyimpangan dalam Penulisan Al-Quran, h. 109.

${ }^{32}$ Muhammad Husain Ad-Dzahabi, Penyimpangan-Penyimpangan dalam Penulisan Al-Quran, h. 121.

${ }^{33}$ Dikutip dari majalah Liwa' al-Islam, 25 Jan 2011 , Volume 29, h. 12.
} t.th), jilid 1,cet II, h. 101. 970. 
Quran yang demikian, bagi mereka, menjadi batu sandung yang ada di tengah yang akan dilalui oleh orang-orang yang bermaksud masuk Islam. ${ }^{34}$

9. Pengabain Kaidah-Kaidah Tafsir

Para pakar dalam bidang apapun memiliki jalan tersendiri ketika hendak memahami dan mengerti ilmu terkait yang hendak dikuasai. Begitupun dalam tafsir al-Quran memiliki kaidah-kaidah tersendiri guna menggali kandungankandungan al-Quran. Mengabaikan kaidah-kaidah tafsir berarti mengabaikan kebenaran penafsiran. ${ }^{35}$

\section{Ragam Penyimpangan dalam Tafsir}

Diantara beragam bentuk penyimpangan dalam tafsir, penulis mengelompokkannya sebagai berikut, yakni penyimpangan dalam tafsir historis; penyimpangan dalam tafsir teologis; penyimpangan dalam tafsir sufi; penyimpangan dalam tafsir linguistik; penyimpangan dalam tafsir ilmi dan penyimpangan dalam tafsir modern. Berikut pembahasannya:

1. Penyimpangan dalam Tafsir Historis

Sosio naratif yang dijelaskan di dalam al-Quran bersifat ringkas dalam menuturkan kisah-kisah. Al-Quran tidak menuturkan kisah secara rinci dan detail. Karena yang ditekankan di dalam al-Quran bukanlah alur cerita, akan tetapi subtansi dalam setiap ayat. Al-Quran bukan menitik-beratkan kepada alur ceritanya, akan tetapi pada pesan moral yang dikandungnya. ${ }^{36}$

Contoh perihal ini ialah tentang penafsiran di masa Sahabat Nabi tentang kisah Adam As. Menurut Ad-Dzahabi, di dalam al-Quran saat menjelaskan kisah Nabi Adam As tidak rinci dan sedetail dalam Taurat dan Injil. Seperti misalnya tidak disebutkan terkait nama Surga; letak pohon; dan nama pohon. Ketika itu para sahabat menanyakan kepada orang-orang yang baru memeluk Islam, yaitu orang-orang Ahlul Kitab, seperti Abdullah Ibn Salam dan Ka'ab Ibn Akbar. Sehingga ia menjelaskan tentang kejadian Adam. Yaitu bahwa nama Surganya ialah 'And; letak pohon ada di tengah-tengah Surga; dan Pohonnya bernama pohon kesedihan, dan pohon kesenangan. ${ }^{37}$

2. Penyimpangan dalam Tafsir Teologis

Lahirnya berbagai aliran teologi yang mewarnai dunia Islam bukan menjadi pelerai perbedaan pandangan dalam pemahaman agama, akan tetapi di sisi lain, justru menjadi kesempatan bagi kelompok-kelompok teologis untuk memanfaatkan al-Quran sebagai justifikasi bagi mazhabnya masing-masing. Tentu saja ini merupakan penyimpangan yang nyata, misalnya ialah terkait Qs. Al-Maidah Ayat 55, yang berbunyi:

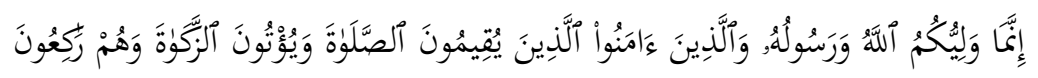

Sesungguhnya penolong kamu hanyalah Allah, Rasul-Nya, dan orang-orang yang beriman, yang mendirikan shalat dan menunaikan zakat, seraya mereka tunduk. (kepada Allab).

${ }^{34}$ Muhammad Husein Adz-Dzahabi, Penyimpangan-penyimpangan Dalam Penafsiran Al-Qur'an, h. 124.

${ }^{35}$ M. Quraish Shihab, Membumikan al-Quran, h. 603-604.

${ }^{36}$ Kuntowijoyo, Paradigma Islam, (Bandung: Mizan, 2008), h. 552.

${ }^{37}$ Muhammad Husain Ad-Dzahabi, Ittijahat al-Munkharifat fi Tafsir al-Quran, h. 27. 
Menurut Sayyid Abdullah al-Alawi - salah satu tokoh Syiah Itsna 'Asy'ariyyah - dalam tafsirnya At-Tafsir li Al-Qur'an al-'Azhim, menyatakan bahwa ayat di atas turun kepada Ali Ibn Abi Thalib. Sewaktu itu ia sedang shalat dan kemudian datang orang yang meminta-minta. Kemudian Ali memberi isyarat dengan tangannya setelah ia melepaskan cincinnya dengan tujuan diberikan kepada peminta tersebut. ${ }^{38}$

3. Penyimpangan dalam Tafsir Sufi

Penyimpangan selanjutnya ialah pada tafsir-tafsir yang menggunakan esoterik dalam memahami ayat-ayat al-Quran. Pendekatan itu kemudian dikuatkan dengan isyarat-isyarat yang didapatkan dari suluk seorang sufi. Salah satu bentuk penafsiran sufi ialah apa yang ditafsirkan oleh Ibn Arabi dalam menafsirkan QS. Al-Baqarah: 67, terkait wabdah al-wujud. Allah Swt berfirman:

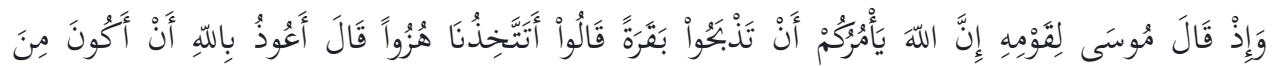

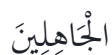

Dan (ingatlah) ketika Musa berkata kepada kaum-nya, "Allah Memerintabkan kamu agar menyembelih seekor sapi betina." Mereka bertanya, "Apakah engkau akan menjadikan kami sebagai ejekan?" Dia (Musa) menjawab, "Aku berlindung kepada Allah agar tidak termasuk, orang-orang yang bodoh."

Ibn Arabi menyatakan bahwa sapi yang disembelih itu merupakan manifestasi dari wujud Allah dan sebagai tempat-Nya. ${ }^{39}$ Tentu saja menimbulkan pemahaman yang membingungkan bagi orang awam. Selain itu, jauhnya makna al-Baqarah (Sapi) dengan disepadankan dengan nama Allah SWt sebagai Tuhan. Sehingga al-Farmawi - sebagaimana dikutip oleh Agus Arifin - menyaratkan beberapa syarat terkait kebolehan tafsir sufi. Yaitu pertama, tidak bertentangan dengan dhabir ayat. Kedua, diperkuat dalil syara' yang lain. Ketiga, tidak bertentangan dengan syariat dan akal sehat. Dan keempat, tidak menganggap penafsirannya sebagai satu-satunya yang benar. ${ }^{40}$

4. Penyimpanyan dalam Tafsir Linguistik

Al-Quran adalah wahyu yang sarat akan makna. Keberadaannya tidak dapat dipahami secara benar sebelum seseorang memahami bahasa Arab dengan baik. ${ }^{41}$ Ini berarti bahwa bahasa Arab memiliki peran yang cukup penting dalam memahami pola-pola kalimat al-Quran guna menafsirkannya. Perihal ini, Muhammad Chirzin menyontohkannya dalam penafsiran Imam Zamakh Syari dala Tafsir al-Kasyaf, yaitu pada QS. Al Isra [17]: 71:

$$
\text { يَوْمَ نَدْعُو كُكََّ أُنَاسِ }
$$

${ }^{38}$ Muhammad Husain Ad-Dzahabi, Ittijahat al-Munkharifat fi Tafsir al-Quran, h. 56.

${ }^{39}$ Dikutip dari, jurnal Panji Masyarakat, (Jakarta: Yayasan Nurul Islam, 1994), Volume 37, Issues 797-801, h. 215.

${ }^{40}$ Agus Arifin dan Suhendri Abdul Faqih, Al-Quran Sang Mabkota Cahaya, Jakarta: Elexmedia Komputindo, 2010), h. 76.

${ }^{41}$ Rasyid Khatib al-Mawshili, Tafsir al-Quran al-Azhim al-Musamma Awla Ma Qila Fi Ayat atTanžil, (Ttp: Mu'assasat Dār al-Kutub, Jzmi'at al-Mawsil, 1971), h. 1. 
(Ingatlah) suatu hari (yang di hari itu) Kami panggil tiap umat dengan pemimpinnya.."

Menurutnya, Zamakhsyari ketika menafsirkan kata "imamihim" maksudnya ialah "ibu-ibu" mereka. Dengan alasan kata tersebut merupakan bentuk jama' dari kata "umm". Penafsiran demikian menurut Chirzin dianggap menyimpang sebab menyelewengkan kaidah bahasa Arab. Dimana pada hakikatnya, kata "umm" sebagai bentuk mufrad memiliki bentuk jama" "ummahat", bukan "imam". 42

5. Penyimpangan dalam Tafsir 'Ilmi

Betul klaim mufaisir ilmi bahwa al-Quran merupakan wahyu yang memuat segala persoalan. Setidaknya al-Quran mendukungnya, sebagaimana dalam Qs. Al-An'am ayat 38 ${ }^{43}$. Namun yang menjadi persoalan ialah manakala al-Quran dijadikan sebagai buku ilmu pengetahuan yang dijadikan sebagai justifikasi kebenaran empirik ilmu-ilmu alam. Karena al-Quran mengandung prinsip-prinsip yang mandiri yang manusia dapat mengembangkannya. Dalam artian, tidak mencocok-cocokan semaunya pembaca al-Quran. Perihal ini, AdDzahabi menjelaskan bahwa salah satu dari tafsir ilmi yang diklaim sebagai menyimpang, ialah Tafsir Tanthawi Jauhari, ketika menafsirkan Qs. Al-Baqarah Ayat 61:

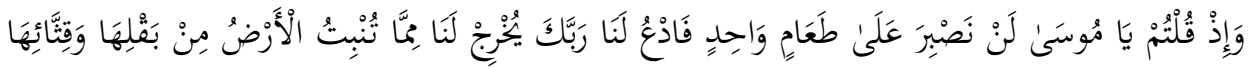

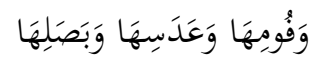

Dan (ingatlab), ketika kamu berkata: "Hai Musa, kami tidak bisa sabar (tahan) dengan satu macam makanan saja. Sebab itu mohonkanlah untuk kami kepada Tubanmu, agar Dia mengeluarkan bagi kami dari apa yang ditumbubkan bumi, yaitu sayur-mayurnya, ketimunnya, bawang putibnya, kacang adasnya, dan bawang merabnya".

Masih menurut Adz-Dzahabi, ketika Tanthawi Jauhari menafsirkan ayat di atas ialah menjelskan tentang faidah-faidah dan manfaat sayur-sayuran di atas dalam kaitannya dengan kesehatan. Kemudian ia sambung dengan penjelasan tentang kedokteran Eropa, dan ia kemudian menyatakan bahwa kedokteran di Eropa ketika menentukan sayuran-sayuran sebagai obat dan kesehatan, itu sesuai dengan al-Quran. ${ }^{44}$

6. Penyimpangan dalam Tafsir Modern

Modernasi dalam Islam merupakan suatu keharusan jika Islam tidak ingin dianggap sebagai agama yang out to date. Akan tetapi tidak berarti kemudian menciptakan bentuk-bentuk penafsiran yang tidak sesuai prosedur dan proposional. Perihal ini sebagaiaman salah satu penafsiran Tanthawi Jauhari ketika menafsirkan Qs. Al-Anbiya Ayat 81:

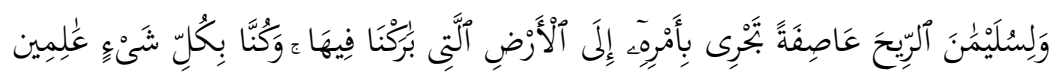

${ }^{42}$ Muhammad Chirzin. 2003. Permata Al-Quran. Yogyakarta: Qirtas. h. 85.

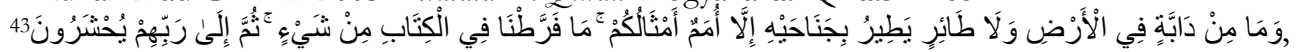
artinya: Dan tiadalab binatang-binatang yang ada di bumi dan burung-burung yang terbang dengan kedua sayapnya, melainkan umat (juga) seperti kamu. Tiadalah Kami alpakan sesuatupun dalam Al-Kitab, kemudian kepada Tuhanlah mereka dibimpunkan.

${ }^{44}$ Muhammad Husain Ad-Dzahabi, Ittijahat al-Munkharifat fi Tafsir al-Quran, hal. 89. 
Dan (telah Kami tundukekan) untuk. Sulaiman angin yang sangat kencang tiupannya yang berhembus dengan perintahnya ke negeri yang kami telah memberkatinya. Dan adalah Kami Maha Mengetabui segala sesuatu.

Menurutnya, negeri yang dimaksudkan di atas ialah Negeri-negeri di Eropa, yang diibaratkan perintahnya itu dengan menggunakan Telegram dan atau Telpon. ${ }^{45}$

\section{Efek-Efek Negatif Bagi Aqidah Islam}

Sebagaimana di atas telah disebutkan bahwa penyimpangan-penyimpangan tafsir al-Quran bisa terjadi di dalam corak-corak tafsir itu sendiri, termasuk ialah di dalam tafsir-tafsir teologis yang bermuara kepada keyakinan umat Islam atas agamanya sendiri. Dari penjelasan-penjelasan sebelumnya, penyimpanganpenyimpangan tafsir al-Quran dapat memberikan efek-efek negatif kepada aqidah umat Islam, yaitu sebagai berikut:

1. Menganggap ajaran Islam tidak otentik

Jika kita telaah kembali penjelasan di atas, maka beberapa tafsir yang menyimpang ialah menjadkan kisah-kisah orang Yahudi dan Nashrani sebagai penafsiran al-Quran. Selain itu, terdapat pemalsuan di dalam muatan-muatan hadis yang tidak menyertakan sanad-sanadnya secara lengkap. Hemat penulis, hal tersebut demikian berakibat negatif kepada ajaran-ajaran Islam, yaitu akan muncul anggapan bahwa ajaran Islam tidak otentik dari Allah Swt, melainkan saduran dan atau refleksi dari ajaran-ajaran Yahudi dan Nashrani, serta bersumber dari nash-nash yang tidak sama sekali diambil dari Nabi Muhammad Saw yang asli (hadis sahih).

2. Mencampuradukan agama Islam dengan non-Islam,

Dengan adanya penyimpangan-penyimpangan di dalam tafsir alQuran yang menjadikan ajaran dan atau inspirasi dari orang non-Islam, secara otomatis hal itu akan mencampuradukan ajaran Islam dengan ajaran nonIslam. Dengan begitu, aqidah umat Islam menjadi tidak murni. Aqidah umat Islam hanya menjadi bahan pelengkap dari ajaran-ajaran non-Islam. Tentu saja hal ini merupakan efek yang sangat berbahaya bagi umat Islam. Sedangkan Islam sendiri ajaran-ajarannya semua datang dari Allah Swt, bukan jiplakan.

3. Sesat memahami kandungan al-Quran

Ketika penyimpangan al-Quran dilakukan, dalam bentuk tafsir apapun, secara tidak langsung Mufassirnya melakukan pembelokan makna alQuran kepada makna yang seharusnya. Karena al-Quran di dalamnya juga terdapat ayat-ayat akidah, maka melakukan penyimpangan dalam ayat-ayat akidah akan berdampak negatif kepada akidah umat Islam, yang bisa jadi salah. Hal ini sangat berbahaya bagi akidahnya umat Islam yang padahal sudah digarisbawahi dalam ayat-ayat al-Quran dan melalui tafsir yang sesuai.

4. Merendahkan ulama salaf (Mufassir terdahulu)

Kita yakini bahwa dari mulai Nabi Muhammad Saw hingga para sahabtnya semuanya menafsirkan al-Quran dengan benar. Sebab para Sahabat juga mendengar langsung apa yang dijelaskan Nabi melalui firman Allah Swt tersebut. Ketika penyimpangan dalam tafsir dilakukan, berarti secara tidak

${ }^{45}$ Muhammad Husain Ad-Dzahabi, Ittijahat al-Munkharifat fi Tafsir al-Quran, hal. 99. 
langsung juga merendahkan para ulama bahkan nabi, yang telah melakukan penafsiran dengan baik dan benar. Tentu saja, merendahkan Nabi, sahabatNya dan ulama-ulama setelahnya adalah suatu hal yang dilarang dalam agama Islam itu sendiri. Akidah umat pun akan berbelok kepada ulama-ulama yang melakukan penyimpangan tafsir al-Quran. Sehingga kesimpulannya, akidahakidah Nabi tidak akan murni lagi ketika tafsir-tafsir yang menyimpang menggerogoti tafsir-tafsir terdahulu tersebut

\section{Simpulan}

Penyimpangan dalam tafsir al-Quran ialah menyalahgunakan kaidah-kaidah tafsir yang berlaku, yang telah digagas oleh ulama-ulama terdahulu dan atau melakukan penafsiran sebab nafsu belaka, bukan karena ilmu. Penafsiran demikian sangat berbahaya bagi pertumbuhan umat Islam yang menjaidkan al-Quran sebagai sumber utamanya. Lebih-lebih, penyimpangan tafsir al-Quran sangat berbahaya bagi akidah umat Islam, sebab keberadaannya akan mengusik akidah-akidah umat Islam yang sudah diyakini dan akan menjaidkan akidahnya tidak murni lagi, yang disebabkan oleh campuran ajaran-ajaran Islam dan atau hadis-hadis palsu. Oleh demikian tafsir-tafsir yang dianggap menyimpang sudah seharusnya tidak dipublikasiken kepada masyarakat. Hal itu dengan tujuan untuk menjadi aqidah umatumat Islam yang sudah tertata rapih dalam al-Quran dan penafsirannya yang benar

\section{Daftar Pustaka}

Ad-Dzahabi, Muhammad Husain, (1986). Penyimpangan-Penyimpangan dalam Penulisan Al-Quran, Jakarta: CV. Rajawali.

Al-'Akk, Khalid Abdurrahman, Ushul at-Tafsir wa Qawadi`hi, Irak: Dar al- Nukhais, t.th.

Al-Harby, Husain ibn Ali Ibn Husain, (1996). Qawa'id at-Tarjih Inda al-Mufassir: Dirasah Naz̧hariyyah Tabtbiqiyyah, Riyadh: Dar al-Qashim.

Al-Hudhari, Muhammad Ibn Abdilah, Tafsir at-Tabiin, Saudi: Dar al- Wathani, t.th.

Al-Mawshilii, (1971). Rasyid Khatib, Tafsir al-Quran al-Az̧bim al-Musamma Awla Ma Qila Fi Ayat at-Tanzil, Ttp: Mu'assasat Dār al-Kutub, Jzmi'at al-Mawsil.

Al-Wahidi, Abu al-Hasan Ali Ibn Hasan, Al-Wasith FI Tafsir al-Quran wal Majid, Kairo: Dar al-Kutub al-Ilmiyyah, t.th.

Ashiddiqy, Hasbi, (1999.). Sejarah dan Pengantar Ilmu Hadits, Semarang: Pustaka Rizki Putra.

Chirzin, Muhammad, (2003). Permata Al-Quran. Yogyakarta: Qirtas.

Faqih, Agus Arifin dan Suhendri Abdul, (2010). Al-Quran Sang Mabkota Cahaya, Jakarta: Elexmedia Komputindo.

Hadna, Ahmad Musthofa, (1993). Problematika Menafsirkan al-Quran, Semarang: Dina Utama.

Hidayat, Komarudin, (1996). Memahami Bahasa Agama Jakarta: PT Temprint.

Jhon, (1978). The new oxford Illustrated Dictionary, Oxford Univ. Press, USA.

Jurnal Panji Masyarakat, Jakarta: Yayasan Nurul Islam, 1994, Volume 37, Issues 797 801.

Kuntowijoyo, (2008). Paradigma Islam, Bandung: Mizan.

Liwa' al-Islam, 25 Jan 2011 , Volume 29. 
Ma'rifah, Muhammad Hadi, At-Tafsir wal Mufassirun, Iran: Muassisah Li At’Tab' wa al-Nashr, t.th.

Munawwar, Said Agil Husain, (1994). Ijaz al-Quran dan Metodoogi Tafsir, Semarang: Dina Utama.

Nurdyanto, dkk, (2016.). Kamus Besar Bahasa Indonesia, Jakarta: Badan Pengembangan dan Pembinaan Bahasa.

Qhaththan, Manna Khalil, Mabahis Fi Ulum al-Quran, Mesir: Maktabah Wahbiyyah, t.th.

Rachim, Abdur, (1989). Tafsir Kontekstual, majalah al-Jami'ah; IAIN Sunan Kalijaga.

Shihab, M. Quraih, (2007). Kaidah-Kaidab Tafsir, Tangerang: Lentera.

Shihab, M. Quraish, (2010). Membumikan al-Quran, Tangerang: Lentera Hati.

Sulaiman , Ahmad Yusuf, (2011). Asbab al-Ikbtilaf fi Tafsir al-Quran, Kairo: t.pn. Usman,(2009). Ilmu Tafsir, Yogyakarta: Teras.

Sulaiman, Abdurrahman Ibn Salih Ibn, al-Ahwal al-Syaddah fi-Tafsir, Saudi: Silsilah Ishdariyyat, t.th.

Sulaiman, Shabur Hasan Muhammad Abu,(1982). Maurid ad-Dham'an Fi Ulum alQuran, India: Dar as-Salafiyyah. 